\title{
NEW SUNDEW QUINONE AND EMERGENCE DATA
}

JAN SCHLAUER •Zwischenstr. 11 •D-60594 Frankfurt/Main•Germany • jan@carnivorousplants.org Siegfried R. H. Hartmeyer, Irmgard Hartmeyer • Wittlinger Str. 5 • D-79576 Weil am Rhein

- Germany•s.hartmeyer@t-online.de

Holger HenNern, ANJA HenNERn • Marktstr. 15・D-44866 Bochum•Germany• hennern@arcor.de

Keywords: Drosera, phytochemistry, naphthoquinones, chemotaxonomy, micro-morphology, emergences.

\section{Introduction}

The acetogenic naphthoquinones, plumbagin ( $\mathrm{P}$ in this paper) and ramentaceone (7-methyljuglone, $\mathrm{M}$ in this paper) are important chemotaxonomic markers in sundews (Drosera L., Culham \& Gornall 1994, Schlauer et al. 2017, 2018). Further accessions have been investigated, and the results are presented and discussed here.

Materials and methods

All plants used in the present study were raised from seed or obtained as cultivated specimens from Sonja Schweitzer (Schermbeck): D. linearis, D. uniflora; Kamil Pasek (Ostrava-Poruda): D. neocaledonica; Carni Flora BV (Aalsmeer): D. cf. paradoxa. Tubers of species in D. sections Erythrorhiza, Stolonifera and Ergaleium were obtained from Greg Bourke (Sydney) and Darren O'Brien (Perth), respectively. The geographic origin of all accessions was traced as far as possible (see Table 1). The methods used were the same as detailed previously (Schlauer et al. 2018). Voucher specimens of the investigated plants were deposited in the first author's private herbarium.

\section{Results}

Naphthoquinones were detected in all investigated samples except in D. major as summarized in Table 1.

\section{Discussion}

The presence of $\mathrm{P}$ (and absence of M) in D. sections Erythrorhiza and Ergaleium confirms the notion by Culham and Gornall (1994) that P is characteristic in most tuberous sundews while M appears to prevail in $D$. sect. Stolonifera instead.

The absence of naphthoquinones is common in pygmy sundews (D. sect. Bryastrum) and in D. sect. Lasiocephala, so the detection of P in D. banksii (Fig. 1) (the first and so far the only known quinone-producing representative in the latter section) may indicate that this species is close to the branching point at which the ability to produce acetogenic quinones was lost in this alliance.

Drosera serpens is a species in D. sect. Arachnopus that shows a fairly wide variability in its indumentum and in size. But even the unusually vigorous plant investigated in this study contained $\mathrm{P}$ that has so far invariably been detected in $D$. serpens. 


\begin{tabular}{|c|c|c|c|c|}
\hline Taxon & Provenance & Drosera section & Quin. & Reference/Remark \\
\hline $\begin{array}{l}\text { Drosera aberrans } \\
\text { (D. whittakeri subsp. } \\
\text { aberrans })\end{array}$ & Vic., Australia & Erythrorhiza & $\mathrm{P}$ & $\begin{array}{l}\text { Culham \& Gornall (1994) } \\
\text { reported P in D. whittakeri. }\end{array}$ \\
\hline D. lowriei & W.A., Australia & Erythrorhiza & $\mathrm{P}$ & new (this study) \\
\hline $\begin{array}{l}\text { D. major } \\
\text { (D. bulbosa subsp. } \\
\text { major) }\end{array}$ & W.A., Australia & Erythrorhiza & 0 & $\begin{array}{l}\text { Culham \& Gornall (1994) } \\
\text { reported P in D. bulbosa. }\end{array}$ \\
\hline D. tubaestylis & W.A., Australia & Erythrorhiza & $\mathrm{P}$ & new (this study) \\
\hline $\begin{array}{l}\text { D. rupicola } \\
\text { (D. stolonifera } \\
\text { subsp. rupicola) }\end{array}$ & W.A., Australia & Stolonifera & M & $\begin{array}{l}\text { Culham \& Gornall (1994) } \\
\text { reported P in this taxon and } \\
\mathrm{M} \text { in D. stolonifera (subsp. } \\
\text { stolonifera). }\end{array}$ \\
\hline D. menziesii & W.A., Australia & Ergaleium & $\mathrm{P}$ & $\begin{array}{l}\text { Culham \& Gornall (1994) did } \\
\text { not detect quinones in this } \\
\text { taxon. }\end{array}$ \\
\hline D. modesta & W.A., Australia & Ergaleium & $\mathrm{P}$ & $\begin{array}{l}\text { confirms Culham \& Gornall } \\
\text { (1994). }\end{array}$ \\
\hline $\begin{array}{l}\text { D. planchonii } \\
\text { (D. macrantha } \\
\text { subsp. planchonii) }\end{array}$ & Australia & Ergaleium & $\mathrm{P}$ & $\begin{array}{l}\text { Culham \& Gornall (1994) did } \\
\text { not detect quinones in this } \\
\text { taxon. }\end{array}$ \\
\hline D. banksii & N W.A., Australia & Lasiocephala & $\mathrm{P}$ & new (this study) \\
\hline D. cf. paradoxa & northern Australia & Lasiocephala & 0 & new (this study) \\
\hline D. aquatica & N.T., Australia & Arachnopus & M & confirms Schlauer et al. (2017) \\
\hline D. indica & Ivory Coast & Arachnopus & $\mathrm{M}+\mathrm{P}$ & $\begin{array}{l}\text { confirms Culham \& Gornall } \\
\text { (1994) and Schlauer et al. } \\
(2018)\end{array}$ \\
\hline D. nana & N.T., Australia & Arachnopus & M & new (this study) \\
\hline $\begin{array}{l}\text { D. serpens } \\
\text { (very large plant) }\end{array}$ & N W.A., Australia & Arachnopus & $\mathrm{P}$ & confirms Schlauer et al. (2017) \\
\hline D. affinis & NE Namibia & Ptycnostigma & $\mathrm{P}$ & new (this study) \\
\hline D. cistiflora & South Africa & Ptycnostigma & M & $\begin{array}{l}\text { confirms Culham \& Gornall } \\
\text { (1994). }\end{array}$ \\
\hline D. uniflora & S Chile & Psychophila & M & new (this study) \\
\hline $\begin{array}{l}\text { D. capillaris } \\
\text { (long petiole) }\end{array}$ & Florida, USA & Drosera & M & \multirow{2}{*}{$\begin{array}{l}\text { Durand \& Zenk (1974) reported } \\
\text { P in this taxon (not mentioned in } \\
\text { Culham \& Gornall 1994). }\end{array}$} \\
\hline D. capillaris & Florida, USA & Drosera & M & \\
\hline D. felix & Venezuela & Drosera & M & new (this study) \\
\hline $\begin{array}{l}\text { D. filiformis var. } \\
\text { filiformis }\end{array}$ & Florida, USA & Drosera & M & $\begin{array}{l}\text { confirms Culham \& Gornall } \\
\text { (1994). }\end{array}$ \\
\hline $\begin{array}{l}\text { D. filiformis var. } \\
\text { floridana }\end{array}$ & Florida, USA & Drosera & M & new (this study) \\
\hline D. linearis & Michigan, USA & Drosera & M & new (this study) \\
\hline D. neocaledonica & New Caledonia & Drosera & M & new (this study) \\
\hline D. ultramafica & Philippines & Drosera & $\mathrm{M}+\mathrm{P}$ & new (this study) \\
\hline
\end{tabular}




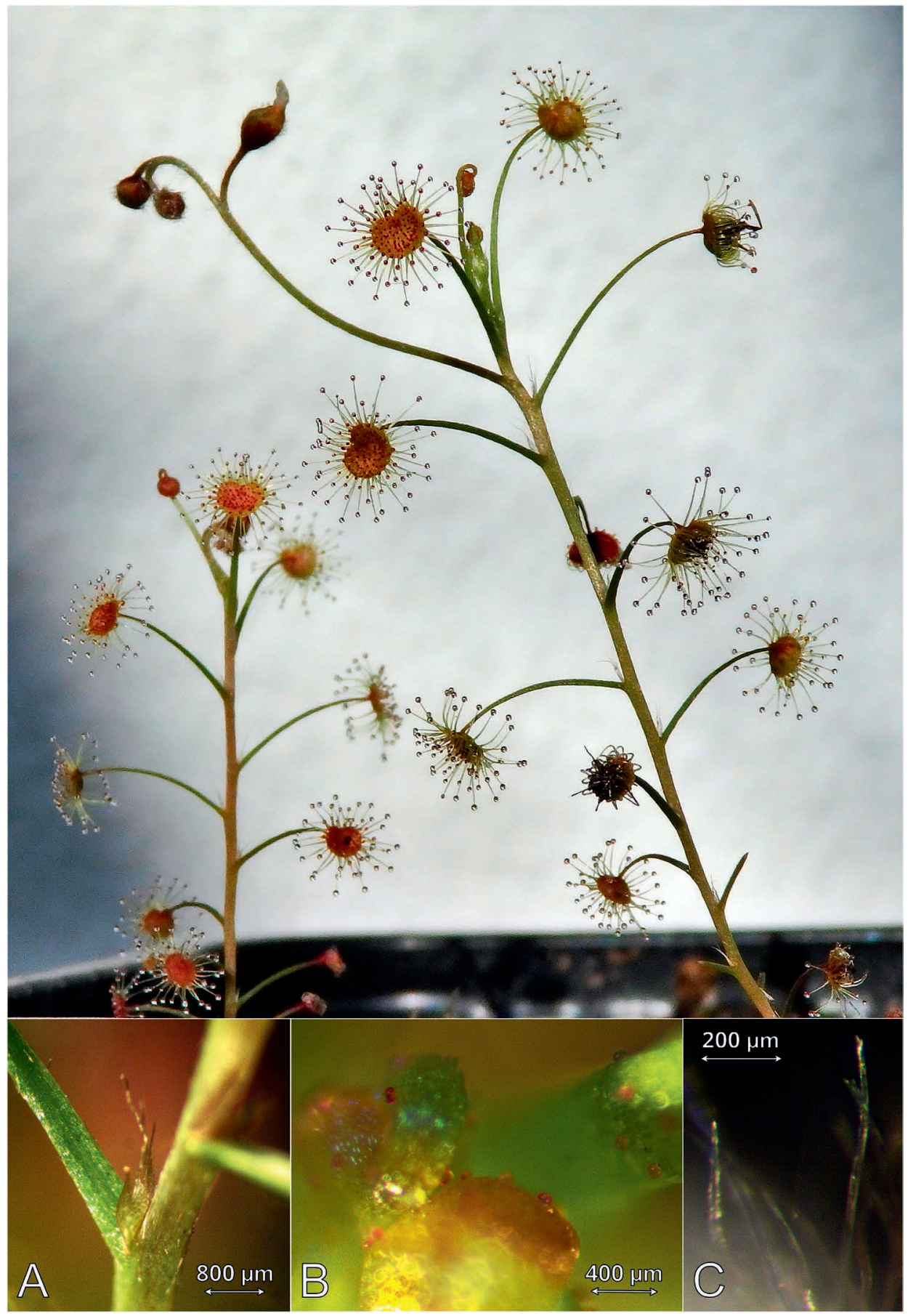

Figure 1: Drosera banksii. Background: mature plant; A: leaf base with stipule; B: red sessile glands on leaves; C: multiseriate hairs on sepals. All photos: S. Hartmeyer. 


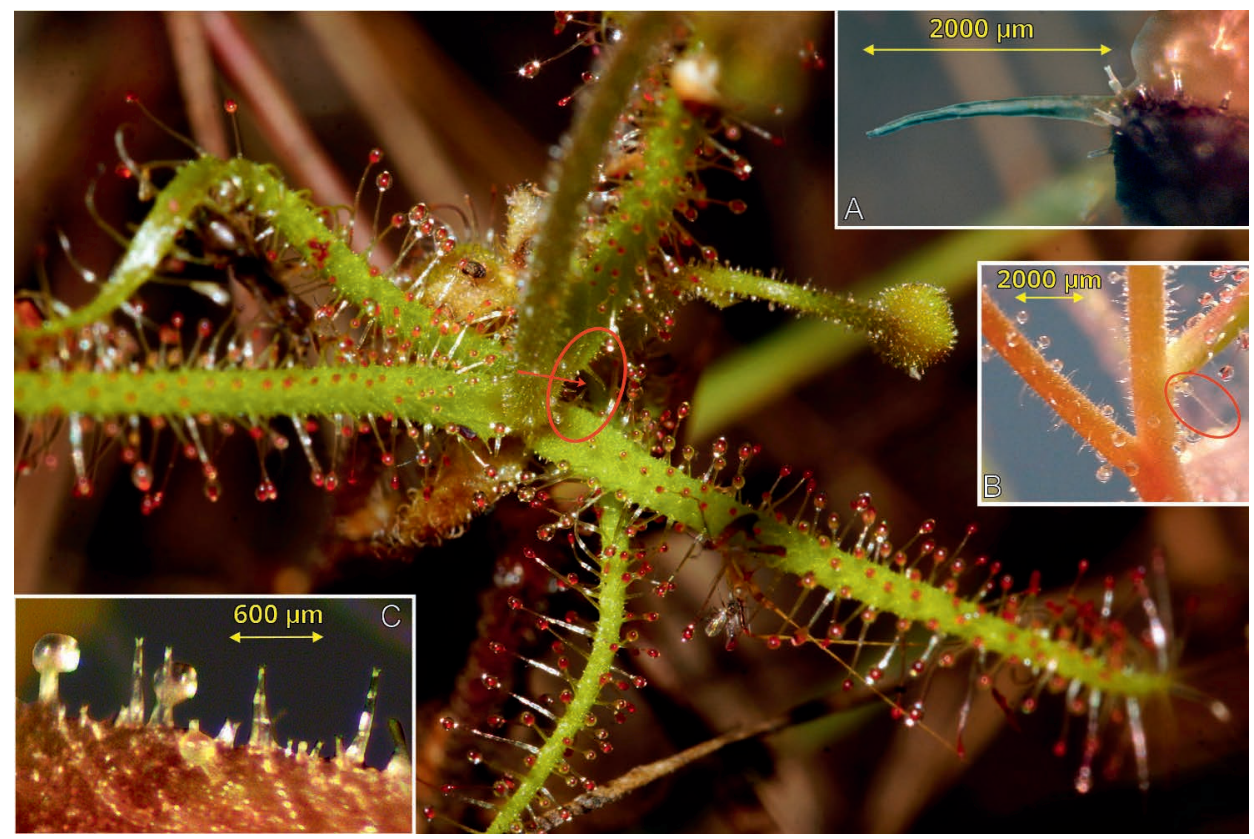

Figure 2: Drosera nana. Background: mature stem with leaf bases showing lateral "stipuloid" emergences at leaf bases (arrow and red oval); A: "stipuloid" emergence at side of leaf base; B: elongated double-tipped caps ("hairs") and stalked glands on stem and pedicel; C: double-tipped cap emergences. Background photo: H. and A. Hennern, remaining photos: S. Hartmeyer.

Drosera nana ( $\mathrm{M}$ in all three distinct populations studied) is occasionally regarded a dwarfed close relative of $D$. aquatica, and its quinone pattern is in line with this view (cf. Schlauer et al. 2017). Also, the indumentum is similar (Fig. 2, cf. Schlauer et al. 2018) with a predominance of conspicuously elongated double-tipped cap emergences especially along the stems. Frequently "stipuloid" emergences (likewise elongated, double-tipped caps) that are somewhat obscured by the dense stem indumentum are found on either side of the leaf base.

Drosera indica s.str. has been investigated several times before, and the present study discloses that plants from Africa share the same quinone pattern with their Asian conspecifics. As this species is the only known representative of $D$. sect. Arachnopus that contains both $\mathrm{M}$ and $\mathrm{P}$ (which suggests a hybrid origin, cf. Schlauer \& Fleischmann 2016), the present result indicates that the hypothetical hybridization event must have occurred before the spread of this species to Africa (where no other species of D. sect. Arachnopus is known).

Drosera sect. Ptycnostigma has been redefined recently (Fleischmann et al. 2018) to contain all African species except D. regia (D. subgen. Regiae) and D. indica (D. sect. Arachnopus). Almost all species of $D$. sect. Ptycnostigma studied so far contained M, so the detection of $\mathrm{P}$ in $D$. affinis provides a valuable tool to define a subgroup of the stem-forming species.

Drosera uniflora is the first species of $D$. sect. Psychophila investigated for naphthoquinones. The presence of M confirms gene sequence data (Rivadavia et al. 2003) that place it close to $D$. sect. Drosera which likewise contains $\mathrm{M}$ in the vast majority of its species. 


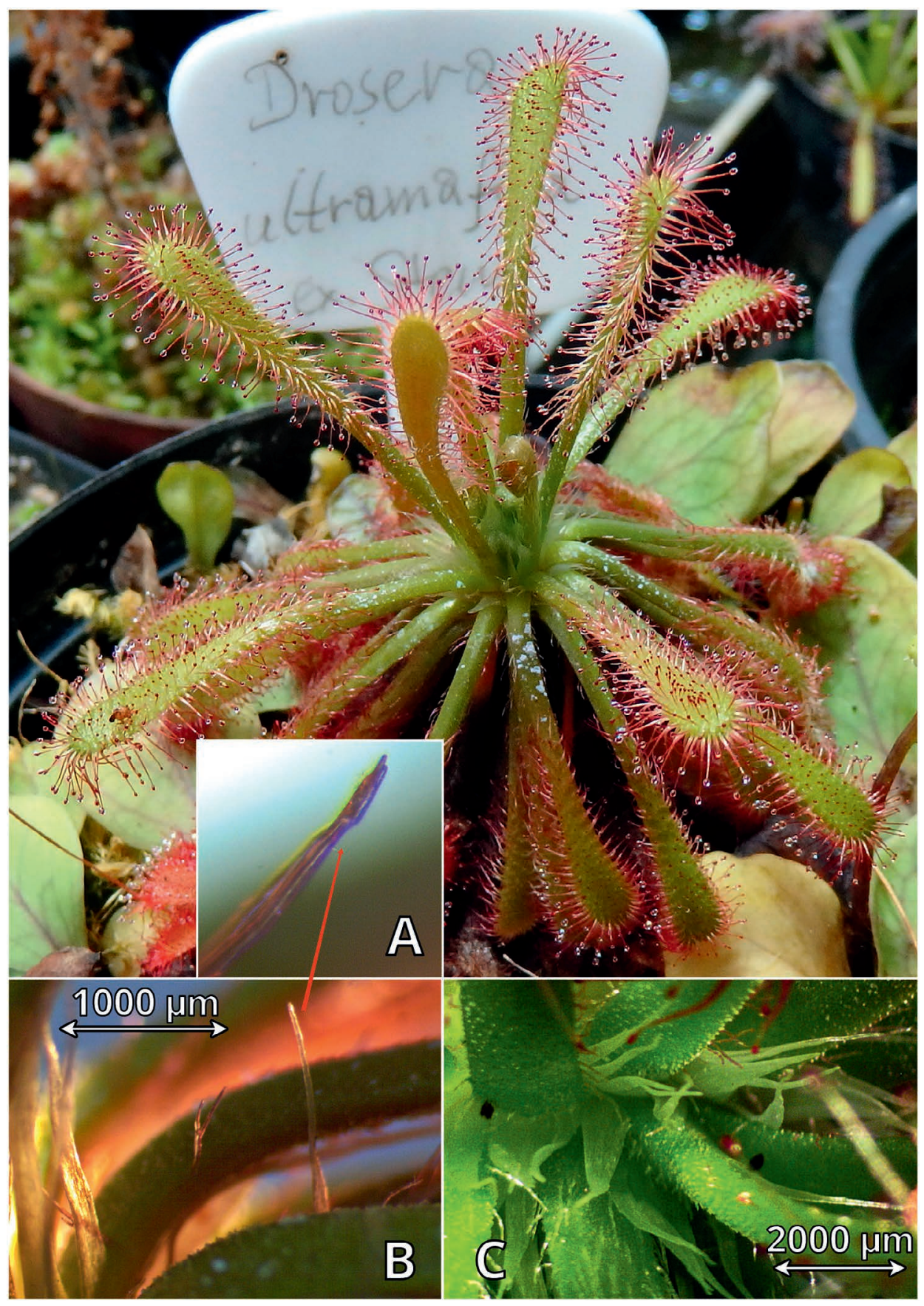

Figure 3: Drosera ultramafica. Background: mature plant; A: magnified tip of multiseriate hair (B); B: multiseriate hair; C: leaf bases with stipules and hairs. All photos: S. Hartmeyer. 


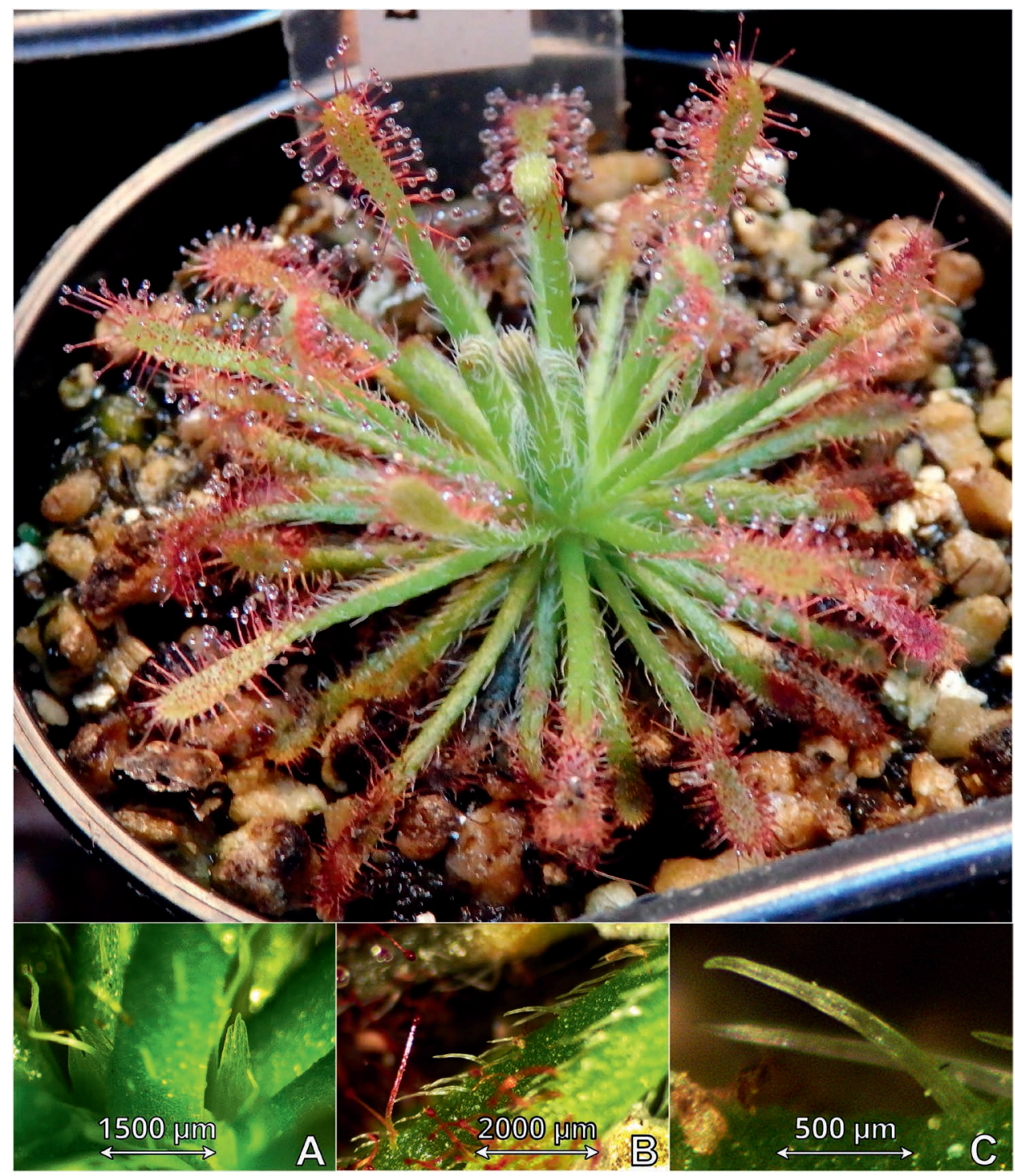

Figure 4: Drosera neocaledonica. Background: mature plant; A: leaf base with stipule and hairs; B: leaf with multiseriate hairs; C: magnified multiseriate hair. All photos: S. Hartmeyer

An unusually long petiole in some individuals of $D$. capillaris from Florida has prompted the suspicion that these may be hybrids with $D$. intermedia. A previous investigation reported $\mathrm{P}$ from D. capillaris, and $D$. intermedia is likewise known to contain this quinone, so hybrids could be expected to be impossible to distinguish from either parent by their quinone pattern. Our investigation of a "typical" individual of $D$. capillaris (with short petioles) from Florida has, however, demonstrated that it contains M. The presence of only this same quinone in the long-petiolate plant grown from seed (i.e., evidently from a fertile mother) and investigated here is not sufficient to prove its hybrid nature. 
The presence of both $\mathrm{M}$ and $\mathrm{P}$ in $D$. ultramafica (see discussion for $D$. indica above) indicates a hybrid origin. While the morphologically somewhat similar D. neocaledonica (cf. Figs. 3 and 4) contains $\mathrm{M}$, the other parent (that contributed the ability to produce $\mathrm{P}$ ) is somewhat enigmatic, as no close relative of $D$. ultramafica containing $\mathrm{P}$ is known in SE Asia.

Acknowledgements: This work was supported by the generous donation of seeds of $D$. indica by Matt Hochberg (New York), of D. capillaris and D. capillaris "long petiole" by Brian Barnes (Longwood), and D. ultramafica by Stewart McPherson (Poole), for which we have the pleasure to express our gratitude. We appreciate the careful review and constructive suggestions by Paulo Gonella and Andreas Fleischmann that have led to the improvement of this paper.

\section{References}

Culham, A., and Gornall, R.J. 1994. The taxonomic significance of naphthoquinones in the Droseraceae. Biochem. Syst. Ecol. 22: 507-515.

Durand, R., and Zenk, M.H. 1974. The homogentisate ring-cleavage pathway in the biosynthesis of acetate-derived naphthoquinones of the Droseraceae. Phytochemistry 13: 1483-1492.

Fleischmann, A., Gonella, P.M., and Rivadavia, F. 2018. A new sectional name for the Brazilian tetraploid clade of Drosera subgenus Drosera. Carniv. Pl. Newslett. 47: 4-9.

Rivadavia, F., Kondo, K., Kato, M., and Hasebe, M. 2003. Phylogeny of the sundews, Drosera (Droseraceae), based on chloroplast $r b c L$ and nuclear 18S ribosomal DNA sequences. Amer. J. Bot. 90: 123-130.

Schlauer, J., and Fleischmann, A. 2016. Chemical evidence for hybridity in Drosera (Droseraceae). Biochem. Syst. Ecol. 66: 33-36.

Schlauer, J., Hartmeyer, S.R.H., and Hartmeyer, I. 2017. Unexpected discovery of 7-methyljuglone (ramentaceone) in several Australian sundews. Carniv. Pl. Newslett. 46: 20-22.

Schlauer, J., Hartmeyer, S.R.H., Hartmeyer, I., Hennern, H., and Hennern, A. 2018. Sundew chemistry and emergence updates. Carniv. P1. Newslett. 47: 10-17.

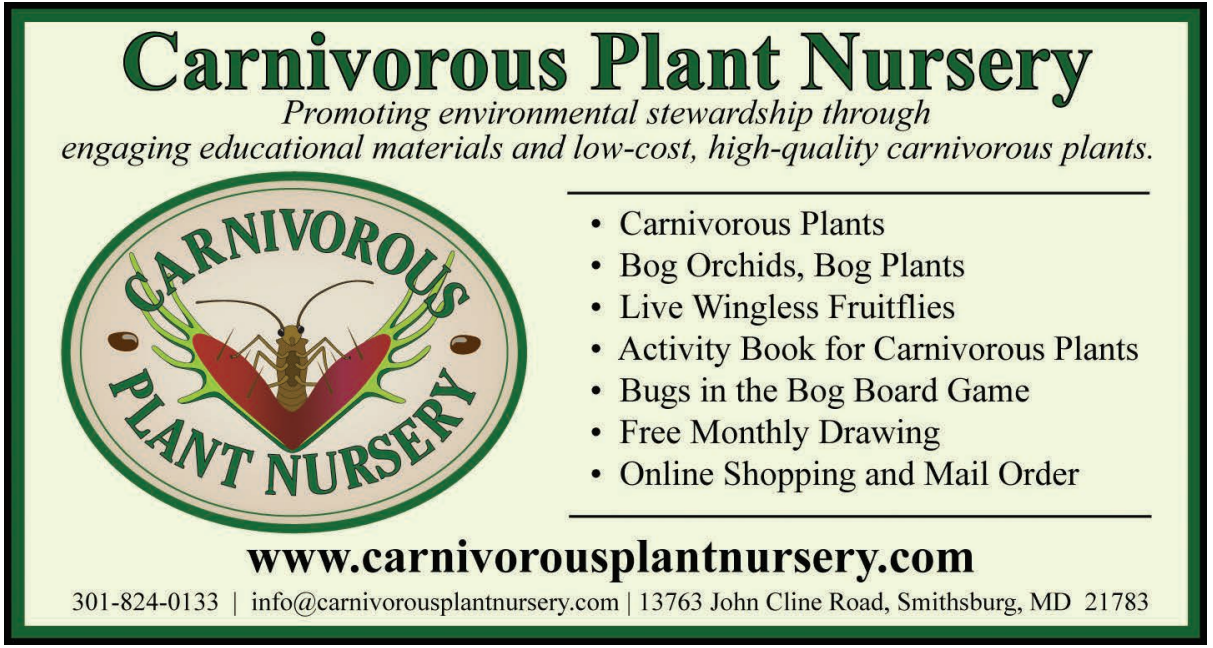

